\title{
REALIZACJA IDEI SPOLECZNEJ GOSPODARKI RYNKOWEJ W POLSKIM USTROJU PRACY
}

Fundamentalne zmiany ustrojowe, które nastapiły w Polsce po 1989 r., objęły także transformację ustroju pracy. Już w exposé premiera Tadeusza Mazowieckiego, wygłoszonym 24 sierpnia 1989 r., użyte zostało pojęcie „społeczna gospodarka rynkowa”, jako określenie pożądanego modelu ustroju społeczno-gospodarczego. Początkowo jednak społeczna gospodarka rynkowa nie była pojęciem prawnym. Zmiany przepisów konstytucyjnych w pierwszych latach III RP nie doprowadziły do określenia w sposób bezdyskusyjny charakteru powstającej w Polsce gospodarki rynkowej. Zwolennicy modelu społecznej gospodarki rynkowej upatrywali podstawy prawnej tego ustroju w art. 1 Konstytucji z 1952 r., w brzmieniu po nowelizacji z 29 grudnia 1989 r. ${ }^{1}$ Określono w nim Rzeczpospolitą Polska jako demokratyczne państwo prawne, urzeczywistniające zasady sprawiedliwości społecznej. Za szczególnie istotne uznawano wskazanie koncepcji sprawiedliwości społecznej, które wymagaja „brania pod uwagę nie tylko ekonomicznych efektów zatrudnienia, lecz także humanistycznego aspektu pracy, traktowanej nie tylko jako podstawowy czynnik tworzący wartości ekonomiczne [...], lecz jako element samorealizacji człowieka"2. Zatem podkreślenie w art. 1 Konstytucji roli zasad sprawiedliwości społecznej w ustroju państwa, wskazywało właśnie na model społecznej gospodarki rynkowej.

Kierunek transformacji zdefiniowany został więc u samego zarania III RP, a niebudząca wątpliwości podstawę normatywną zyskał wraz z wejściem w życie Konstytucji z 2 kwietnia $1997 \mathrm{r}^{3}{ }^{3} \mathrm{~W}$ świetle jej art. 20 społeczna gospodarka rynkowa jest normatywnym modelem społeczno-gospodarczego ustroju RP. Od początku transformacji syntetyczne ujęcia przemian rynku pracy, jak też analizy poszczególnych jego instytucji, podkreślały zwykle dynamikę sytuacji, związaną z kształtowaniem się nowego ustroju pracy. Mankamenty regulacji prawnej i praktyki stosunków społecznych przypisywane były często niedopełnieniu się transformacji, której postępy miały doprowadzić do

${ }^{1}$ Art. 1 ust. 4 ustawy z 29 grudnia 1989 r. o zmianie Konstytucji Polskiej Rzeczypospolitej Ludowej, Dz. U. Nr 75, poz. 444.

${ }^{2}$ Z. Ziembiński, Wartości konstytucyjne, Warszawa 1993, s. 87.

${ }^{3}$ Dz. U. Nr 78, poz. 483. 
likwidacji zaszłości gospodarki socjalistycznej, sanacji rynku pracy i ukształtowania społecznej gospodarki rynkowej.

Jubileusz ćwierćwiecza sformułowania tego kierunku przemian skłania do refleksji nad zakresem realizacji idei społecznej gospodarki rynkowej w polskim ustroju pracy. Upływ czasu upoważnia już do poddania efektów transformacji ustroju pracy analizie w kategorii procesów dokonanych, a nie dokonujących się. Co prawda zarówno system prawny, jak i praktyka społeczna podlegają stałym zmianom, wydaje się jednak, że nie mamy obecnie do czynienia z kontynuacją rewolucyjnych procesów transformacyjnych, lecz z ewolucja szczegółowych aspektów ustroju, niezbędną dla dostosowania go do nowych zjawisk gospodarczych i społecznych.

Podstawowym dla omawianego zagadnienia przepisem jest art. 20 Konstytucji, który ustanawia społeczną gospodarkę rynkowa, opartą na wolności działalności gospodarczej, własności prywatnej oraz solidarności, dialogu i współpracy partnerów społecznych, jako model ustroju gospodarczego Rzeczypospolitej. Regulacja ta wskazuje typ gospodarki rynkowej, którego ukształtowanie powinno być celem działalności legislacyjnej, a także główne wartości, które stanowią podstawę tego modelu ustrojowego. Zakres ochrony tych wartości i ich praktyczne oddziaływanie może być podstawą oceny stopnia realizacji zasad społecznej gospodarki rynkowej w polskim ustroju pracy.

Pojęcie społecznej gospodarki rynkowej ma istotne znaczenie dla ustroju pracy, determinuje bowiem specyficzny model stosunków przemysłowych, które się z nim wiąża. Jest ono ważne także dla regulacji prawa pracy, gdyż określa instrumentalną wartość tej gałęzi prawa dla związanego ze społeczną gospodarką rynkową szczególnego typu ustroju społecznego i gospodarczego.

Nie istnieje jednolity model społecznej gospodarki rynkowej, w literaturze wskazuje się, że nawet $\mathrm{w}$ powojennych Niemczech ${ }^{4}$ koncepcja ta ewoluowała wraz z praktyką jej wdrażania ${ }^{5}$. Omawiany model gospodarki opiera się jednak na podstawowych niezmiennych założeniach. Istotą społecznej gospodarki rynkowej jest próba połaczenia konkurencyjnego mechanizmu rynkowego w zakresie wytwórczości (produkcji) z bardziej równomiernym podziałem w społeczeństwie efektów wzrostu gospodarczego, niż ma to miejsce w gospodarce liberalnej. Wcześniej ekonomiczne koncepcje ustroju gospodarczego koncentrowały się na analizie efektywności różnych typów organizacji procesów

${ }^{4}$ Społeczna gospodarka rynkowa jest koncepcją gospodarczą opracowaną przez ekonomistę Alfreda Müllera-Armacka jeszcze w czasie II wojny światowej na potrzeby powojennych Niemiec. W założeniu miała być próbą przezwyciężenia wad systemu społeczno-gospodarczego międzywojennej Republiki Weimarskiej, w których m.in. upatrywano podłoża rozwoju faszyzmu. Niemcy były więc państwem, dla którego powstała koncepcja społecznej gospodarki rynkowej, a zarazem w tym kraju po raz pierwszy podjęto praktyczną realizację tych idei.

${ }^{5}$ Zob. K. Grimm, Socjalna gospodarka rynkowa w RFN. Koncepcja-rozwój-problematyka, Warszawa 1992, s. 7. 
produkcyjnych (gospodarka rynkowa - gospodarka centralnie sterowana). Odmiennością modelu społecznej gospodarki rynkowej jest m.in. wyeksponowanie znaczenia systemu podziału dóbr, a nie tylko efektywności ich wytwarzania. Wbrew pozorom najistotniejsze nie sa tu dokonywane przez państwo wtórne transfery socjalne, polegające na rozbudowanym systemie wsparcia osób nieradzących sobie z zaspokajaniem życiowych potrzeb. Podstawowe znaczenie ma stworzenie takiego mechanizmu pierwotnego podziału dochodu, który pozwoli możliwie wszystkim zainteresowanym korzystać bezpośrednio z efektów procesów gospodarczych, bez odwoływania się do opiekuńczej roli państwa.

Wzrost gospodarczy uznawany jest za podstawę dobrobytu, którego źródłem ma być społeczna gospodarka rynkowa ${ }^{6}$. Jednakże - inaczej niż w gospodarce liberalnej - wyniki ekonomiczne nie stanowia tu celu samoistnego. Ocena osiagniętych wyników gospodarczych wiąże się ze sposobem podziału ich efektów, który jest jednym z kryteriów organizacji gospodarki. W społecznej gospodarce rynkowej podstawowy cel gospodarowania - maksymalizacja zysku - doznaje ograniczenia przez prawne regulacje, w związku ze społecznymi celami przypisywanymi wzrostowi gospodarczemu?

Zarówno w ekonomicznej koncepcji społecznej gospodarki rynkowej, jak i w jej prawnym pojęciowym zarysie, sformułowanym w art. 20 Konstytucji, zwraca uwagę połączenie antynomicznych wartości związanych z wolnym rynkiem i konkurencja, które eksponują interesy jednostkowe, oraz solidaryzmu społecznego, upodmiotowienia wszystkich uczestników rynku, jako emanacji dobra wspólnego. Konkurencja, jako podstawa efektywności gospodarczej i swobody przedsiębiorczości, jest oczywistym składnikiem każdego typu gospodarki rynkowej, niewystarczajacym jednak do stworzenia systemu społecznego zapewniającego szeroki dostęp do efektów rozwoju dla wszystkich podmiotów zaangażowanych w jego wypracowanie. Społeczna gospodarka rynkowa ma tworzyć materialna podstawę rozwoju jednostek i ich organizacji, jako formę uznania ich podmiotowości i godności. Jej celem jest nie tylko stały wzrost zaopatrzenia w dobra materialne, ale realizacja szerzej pojmowanych wartości ogólnoludzkich, szczególnie wartości społecznych ${ }^{8}$. Mimo uznawania prymatu wolnego rynku w omawianym modelu gospodarki dopuszczalna jest państwowa interwencja w działanie mechanizmu rynkowego dla osiagnięcia celów związanych z wartościami ogólnospołecznymi, takimi jak dostęp do zatrudnienia czy standard pracy godnej.

W społecznej gospodarce rynkowej szczególną rolę przypisuje się aktywności zrzeszeń obywateli i działaniom zbiorowym o określonej przez państwo autonomii. Wynika to z zasady pomocniczości, będącej konsekwencją solidaryzmu społecznego. Prymat aktywności społecznej obywateli i ich organizacji oznacza, że interwencja państwowa jest środkiem ostatecznym. Państwo po-

${ }^{6}$ Zob. ibidem, s. 15.

${ }^{7}$ Zob. K. Strzyczkowski, Konstytucyjna zasada społecznej gospodarki rynkowej jako podstawa tworzenia $i$ stosowania prawa, w: C. Kosikowski (red.), Zasady ustroju społecznego i gospodarczego $w$ procesie stosowania Konstytucji, Warszawa 2005, s. 14.

${ }^{8}$ Ibidem, s. 17. 
winno tworzyć prawne ramy włączania szerokiego kręgu podmiotów w procesy decyzyjne o charakterze zarówno gospodarczym, jak i społecznym. Szczególna partycypacyjna struktura przedsiębiorstwa powinna uwzględniać godność zatrudnionych, jako wytwórców dóbr i współpracowników, oraz umożliwiać im prezentowanie stanowiska i udział w dialogu z zatrudniającym, bez ograniczania inicjatywy i odpowiedzialności przedsiębiorcy.

Wśród regulacji prawnych służących realizacji zasad społecznej gospodarki rynkowej istotne znaczenie ma prawo pracy, jako instrument korekty mechanizmu rynkowego w zakresie podziału dóbr zwiąanych ze świadczeniem pracy zależnej. Prawo pracy może w różnorodny sposób wpływać na realizację idei społecznej gospodarki rynkowej. Eksponowanym kierunkiem oddziaływania jest określenie wzajemnych zobowiązań stron stosunku pracy w sposób odmienny, niż kreuje je nieograniczony wpływ mechanizmu rynkowego. Ważna rolą prawa pracy jest też jednak tworzenie procedur partycypacyjnych na różnych poziomach aktywności gospodarczej, które są podstawą ważnego społecznie przeniesienia procesu decyzyjnego z organów państwa na obywateli. Wartości związane ze społeczna gospodarką rynkowa pozostaja w bezpośrednim związku z podstawami oceny regulacji prawa pracy także dlatego, że idee społecznej gospodarki rynkowej moga być realizowane tylko w warunkach szerokiego dostępu do zatrudnienia realizujacego standard pracy godnej. Dlatego zarówno zakres dostępu do zatrudnienia, jak i jego jakość są sprawami podstawowymi w omawianym modelu gospodarczym.

Zasady solidarności, dialogu i współpracy partnerów społecznych, uzupełniające rynkowy mechanizm gospodarczy, stanowią podstawę systemu wartości odpowiadającego potrzebom aksjologicznego osadzenia regulacji współczesnego prawa pracy. Tworzenie dobrobytu opierać się więc musi na wolności aktywności gospodarczej opartej na konkurencji, które to wartości podlegaja ochronie, co uwzględniać musi cały system prawny. Kwestia ta, w kontekście uwzględniania potrzeb ochrony interesów pracodawców, jest więc aktualna także w wartościowaniu regulacji prawa pracy. Idea solidarności partnerów społecznych jest emanacja filozofii solidaryzmu społecznego, zgodnie z którą życie społeczne opiera się na współzależności i współodpowiedzialności wszystkich jego uczestników. Solidaryzm eksponuje wspólnotę interesów jednostek i grup społecznych, tworzących daną społeczność oraz obowiązek partycypowania w obciążeniach na jej rzecz.

Poszukiwanie wspólnoty interesów podmiotów uczestniczących w rynku pracy jest też przewodnią ideą kształtowania regulacji nowoczesnego prawa pracy w wymiarze zarówno materialnym, jak i proceduralnym. Konsekwencją idei solidarności podmiotów, reprezentujących częściowo rozbieżne interesy, jest postulat równomiernego rozłożenia obciążeń, służących realizacji dobrobytu wspólnoty. Afirmowaną w art. 20 Konstytucji formą ustalania rozwiązań zmierzających do osiagania tego celu jest dialog partnerów społecznych. Pożądaną sytuacją jest przejęcie przez same zainteresowane podmioty kształtowania równowagi między ochroną wartości związanych ze swoboda działalności gospodarczej i ochroną prawa własności a realizacją interesów osób utrzymujących się z osobistego wykonywania pracy. Zadanie państwa 
w tym zakresie powinno polegać przede wszystkim na stworzeniu prawnych ram dialogu społecznego w kontekście proceduralnym, jak też na uznaniu jego materialnoprawnych efektów i włączeniu porozumień społecznych do systemu prawnego. Podstawą partnerstwa społecznego jest zaufanie między podmiotami włączonymi w jego realizację. Dotyczy to nie tylko relacji między przedstawicielami stron stosunku pracy, lecz także zaufania państwa do pozytywnych konsekwencji swobodnego dialogu społecznego. Wyrażać się ono powinno w możliwie szerokim zakresie autonomii, jaka państwo pozostawia partnerom społecznym dla samodzielnego kształtowania ich sytuacji. Zaprzeczeniem zaufania jest narzucanie regulacji proceduralnych ukierunkowujacych i zawężających zakres swobodnej współpracy i dialogu. Zbyt restrykcyjny nadzór państwa nad tą sfera jest odbierany jako wyraz jego niechęci do rezygnacji z władczego wpływu na kształtowanie porządku społecznego i nie sprzyja rozwojowi idei partnerstwa.

Konsekwencją ustanowienia społecznej gospodarki rynkowej, jako modelu ustroju gospodarczego, jest konieczność uwzględniania różnorodnych interesów podmiotów związanych z rynkiem pracy. Regulacji rynku pracy nie powinno się więc oceniać jednoaspektowo, z perspektywy wybranych grup społecznych, na których sytuację oddziałuje. Potrzeba ochrony interesów partykularnych powinna być oceniana w kontekście tworzenia systemu społecznego, związanego z ideą społecznej gospodarki rynkowej.

\section{III}

Pozbawienie w PRL obu stron stosunków pracy niezależnych reprezentacji na poziomie zbiorowym, ograniczenie wolności kształtowania indywidualnych umów o pracę oraz zagarnięcie przez państwo kompetencji decyzyjnych we wszelkich istotnych sprawach zatrudnieniowych wykluczyły możliwość powstania socjalnego partnerstwa, czyli układu życzliwych relacji między stronami stosunków pracy na różnych szczeblach, w których nie abstrahuje się od różnic interesów, lecz rozwiązuje się problemy z poszanowaniem podmiotowości i potrzeb drugiej strony. Teoria stosunków społecznych socjalizmu oparta była na marksistowskiej doktrynie walki klas, która miała wyjaśniać kształtowanie się życia społecznego w państwach kapitalistycznych. Doktryna ta była adekwatna do dziewiętnastwiecznego wczesnego kapitalizmu, lecz nie przystawała do modelu państwa dobrobytu, który ukształtował się w wielu zachodnich państwach europejskich w drugiej połowie XX w. Natomiast paradoksalnie historia PRL, w której najistotniejsze daty oznaczają ostre konflikty między „społeczną bazą” a „nadbudową, ma dużo więcej odniesień do doktryny walki klas niż powojenna historia Europy Zachodniej. Brak procedur, a ze strony władz także brak woli prowadzenia zbiorowych negocjacji na jakimkolwiek szczeblu doprowadziły do sytuacji, w której jedynym środkiem nacisku umożliwiającym poprawę standardów zatrudnienia i życia był ostry konflikt. 
To dziedzictwo okresu PRL - model stosunków społecznych naznaczonych egoizmem, nieufnością i brakiem szacunku dla innych uczestników obrotu obciąża współcześnie próby budowy partnerstwa społecznego w Polsce na wszystkich szczeblach. Brak tradycji negocjacji zbiorowych i w pewnym zakresie także indywidualnych, a także mentalność „,walki klas” występująca u obu stron stosunków pracy stanowią zaprzeczenie idei socjalnego partnerstwa, która jest podstawą ustroju społecznej gospodarki rynkowej. Spuścizna poprzedniego systemu jest nie tylko niedorozwój regulacji autonomicznego prawa pracy, lecz także brak praktyki jego tworzenia. Skutkiem omawianego stanu rzeczy jest niedoświadczenie socjalnych partnerów w kształtowaniu wzajemnych stosunków, co może być jednym z powodów powstawania nieporozumień. Wydaje się, że brak podejścia partnerskiego, zakładającego konieczność uwzględniania także słusznych interesów drugiej strony, jest obecnie przyczyną wielu konfliktów między stronami stosunków pracy. Zmiana ukształtowanego w Polsce antagonistycznego modelu społecznych stosunków pracy może być obecnie bardzo trudna, gdyż nie sprzyja temu model rozwoju światowej gospodarki, wynikający z globalizacji.

\section{IV}

Podstawowymi przejawami partnerstwa społecznego, jako aksjologicznej podstawy ustroju pracy, sa negocjacje zbiorowe i ich materialne efekty - autonomiczne źródła prawa pracy. Niestety, praktyka dialogu społecznego między reprezentacjami pracowników i pracodawców, jak też tworzenie autonomicznych źródeł prawa pracy w Polsce należą do materii ukształtowanych w sposób bardzo odległy od modelu społecznej gospodarki rynkowej. Przyczyny tego stanu rzeczy wiążą się zarówno z partykularnymi zjawiskami polskiego ryn$\mathrm{ku}$ pracy, jak też wynikają z ogólnoświatowych tendencji zatrudnieniowych w erze globalizacji.

W ostatnim ćwierćwieczu w Polsce nastapiła atrofia działalności związków zawodowych. Obecnie jedynie $12 \%$ pracowników to członkowie związów zawodowych ${ }^{9}$. W największej mierze zanik aktywności związów zawodowych widoczny jest na poziomie zakładowym. Jest to szczególnie dotkliwe, gdyż ustawa z 23 maja $1991 \mathrm{r}$. o związkach zawodowych ${ }^{10} \mathrm{i}$ inne regulacje prawa pracy właśnie organizacjom związkowym działającym na terenie jednego zakładu pracy (zakładowe zawiązki zawodowe) przypisują najistotniejsze kompetencje w zakresie reprezentacji interesów pracowniczych - prowadzenia negocjacji zbiorowych, zawierania zakładowych układów zbiorowych pracy lub porozumień zbiorowych, czy wreszcie także prowadzenia sporów zbiorowych. Taka normatywna konstrukcja ruchu związkowego sprzyja w obecnym stanie rzeczy zanikowi działalności związkowej, gdyż rozdrobnienie działalności gospodarczej w Polsce, objawiające się dominacją małych zakładów pracy, po-

${ }^{9}$ Zob. Centrum Badania Opinii Społecznej, Związki zawodowe i prawa pracownicze, komunikat z badań, Warszawa 2012, s. 1, http://www.cbos.pl/SPISKOM.POL/2012/K_052_12.PDF (dostęp: 20.02.2014).

${ }^{10}$ T.jedn.: Dz. U. 2001, Nr 79, poz. 854 ze zm. 
woduje, że niewiele jest przedsiębiorstw wystarczająco dużych, aby zakładowe związki zawodowe mogły w nich powstać. W tej sytuacji jedyną szansa na ewentualną reaktywację związkowej reprezentacji pracowników na szersza skalę wydaje się przeniesienie ciężaru aktywności związków zawodowych na poziom ponadzakładowy (np. branżowy), co umożliwiłoby ukształtowanie reprezentacji adekwatnej do obecnej struktury gospodarki. Ogólnokrajowe centrale związkowe, aktywne i widoczne na ogólnopolskim poziomie politycznym sa jedna z istotnych emanacji ruchu związkowego, ta aktywność jednak powinna służyć wsparciu działalności podstawowej, polegającej na reprezentacji pracowników wobec pracodawców, podczas gdy w Polsce staje się główną formą aktywności związków zawodowych.

Osłabienie aktywności związkowej jest zjawiskiem występującym także w innych krajach, można więc wskazać ponadnarodowe przyczyny tego zjawiska w powszechnej indywidualizacji relacji zatrudnieniowych w ostatnich dekadach ${ }^{11}$. Jednak w Polsce proces ten bez wątpienia ma również podłoże lokalne, związane z wyżej wskazaną eliminacją dialogu społecznego w okresie PRL i tym samym brakiem umiejętności i tradycji jego prowadzenia. Dostrzegany szczególnie po stronie pracodawców brak potrzeby partycypacyjnego kontaktu z załogą i rozwijania współuczestnictwa pracowników i ich reprezentacji w sprawach zakładu pracy powoduje postrzeganie związków zawodowych jako przeszkody w zarządzaniu przedsiębiorstwem i jego załoga. W gospodarczej sferze prywatnej przedsiębiorczości najczęściej istnieje więc środowisko niechętne, a nawet wrogie związkom zawodowym ${ }^{12}$. Zanik działalności związkowej i brak społecznego dialogu są więc zjawiskami ściśle z sobą związanymi i wzajemnie uwarunkowanymi.

Do ograniczenia dialogu społecznego w dziedzinie zatrudnienia przyczynia się też słabość organizacji pracodawców, spowodowana - jak się wydaje nazbyt indywidualistycznym podejściem przedsiębiorców do prowadzonej działalności gospodarczej i brakiem potrzeby wspólnego poszukiwania rozwiązań problemów wraz z innymi pracodawcami, którzy traktowani są głównie jako konkurenci. Słabość głównych podmiotów dialogu społecznego jest podstawowym problemem tworzenia i działania instytucji ustroju pracy opartego na idei społecznej gospodarki rynkowej. Regulacje prawne tworzace ramy ich aktywności nabierają fasadowego charakteru z powodu rzadkiego ich wykorzystywania.

Taką rolę trzeba niestety przypisać układom zbiorowym pracy ${ }^{13}$, które $\mathrm{w}$ wielu krajach sa fundamentem tworzenia prawa pracy, a co do jego treści opierają się na konsensusie społecznym. W dniu 1 stycznia 1995 r. zaczęły obowiązywać przepisy nowego działu XI Kodeksu pracy, uchwalone na potrzeby negocjowania i zawierania tych podstawowych dla prawa pracy aktów

11 Zob. J. Stalina, Zbiorowa reprezentacja pracowników w Polsce - stan obecny i perspektywy, w: Problemy kodyfikacji prawa pracy. Wybrane zagadnienia zabezpieczenia społecznego, Gdańsk 2007, s. 96-102.

12 Zob. J. Gardawski et al., Rozpad bastionu? Zwiazki zawodowe w gospodarce prywatyzowanej, Warszawa 1999, s. 247-256; J. Gardawski, Zwiazki zawodowe na rozdrożu, Warszawa 2001 , s. $126-135$.

${ }^{13}$ Zob. L. Florek, Znaczenie układów zbiorowych pracy, w: Z. Góral (red.), Układy zbiorowe pracy. W stulecie urodzin profesora Wacława Szuberta, Warszawa 2013, s. 64 i n. 
normatywnych w warunkach gospodarki rynkowej ${ }^{14}$. Przepisy te miały stać się podstawą rozwoju regulacji układowej, której tworzenie miało wpływać na stopniowe przekształcanie antagonistycznej formuły społecznych stosunków pracy, dzięki wzajemnym kontaktom, rokowaniom i wspólnemu poszukiwaniu kompromisu. Nowa regulacja układów zbiorowych pracy nie wpłynęła jednak na intensyfikację negocjacji zbiorowych, co - abstrahując od wyżej wskazanych uwarunkowań społecznych - z pewnością związane było także z jej istotnymi wadami, które zniechęciły partnerów społecznych (a szczególnie pracodawców) do zawierania umów normatywnych.

Kwestią szczegółową o wielkiej doniosłości dla systemu układów zbiorowych pracy w Polsce była treść art. $241^{7} \S 4$, będącego podstawą tzw. klauzuli wieczystego obowiązywania układu zbiorowego. Sprowadzała się ona do tego, że postanowienia układu zbiorowego mogły być skutecznie uchylone jedynie za zgodą obu jego stron. Jednostronne wypowiedzenie układu zbiorowego pracy przez którąkolwiek stronę skutkowało jego rozwiązaniem, jego postanowienia podlegały jednak dalszemu stosowaniu, chyba że obie strony oświadczyły wolę ich uchylenia. Wydaje się, że regulacja ta miała w założeniu zapewnić trwałość układom zbiorowym, jednakże oczywistą reakcją przedsiębiorców na takie zasady ich obowiązywania było unikanie wiązania się postanowieniami układowymi, których nie można jednostronnie uchylić nawet wobec zmiany sytuacji gospodarczej. Przepis ten na długo sparaliżował rozwój regulacji układowej, a nawet po jego uchyleniu ${ }^{15} \mathrm{w}$ wielu środowiskach pozostało negatywne skojarzenie układu zbiorowego pracy jako instytucji opresyjnej, służącej utrwalaniu zdezaktualizowanych i niechcianych w zmienionej sytuacji rozwiązań.

Takie skojarzenie jest podsycane przez zbędny przepis art. $241^{2} \S 3 \mathrm{k} . \mathrm{p}$. wskazujący sytuacje, w których strona uprawniona do zawarcia układu nie może odmówić drugiej stronie podjęcia rokowań nad układem zbiorowym. Nakaz ten ma charakter wyjątku, we wszystkich innych przypadkach strony korzystaja ze swobody podjęcia decyzji w tej kwestii. Jednak zakres wyjątków wskazanych w omawianym przepisie został określony na tyle szeroko, że skłania do formułowania wniosku o obowiązku prowadzenia rokowań nad układem zbiorowym ${ }^{16}$. Regulacja ta wzbudza wątpliwości zarówno w aspekcie funkcjonalnym, dotyczącym celu nakładania obowiązku rokowań na stronę, która nie wyraża woli zawarcia układu zbiorowego pracy, jak i formalnym, dotyczącym jej zgodności z zasadą autonomii stron układu zbiorowego pracy. Na gruncie prawa międzynarodowego formułowane są różnorodne poglądy w kwestii przyjmowanego w niektórych krajach, podobnie jak w Polsce, obowiązku przystapienia do rokowań zbiorowych ${ }^{17}$. Niejednoznaczne stanowisko

${ }_{14}$ Zob. ustawa z 29 września 1994 r. o zmianie ustawy - Kodeks pracy oraz o zmianie niektórych ustaw, Dz. U. Nr 113, poz. 547.

15 Zob. wyrok Trybunału Konstytucyjnego z 18 listopada 2002 r., K 37/01, Dz. U. Nr 196, poz. 1660.

${ }^{16}$ Zob. Rączka, Rokowania układowe, „Praca i Zabezpieczenie Społeczne” 1995, nr 4, s. 40-42; L. Florek, T. Zieliński, Prawo pracy, Warszawa 2004, s. 330.

17 Szerzej na ten temat zob. Z. Hajn, Status prawny organizacji pracodawców, Warszawa 1999, s. 80. 
organów uprawnionych do interpretacji norm prawa międzynarodowego w tej sprawie uniemożliwia przyjęcie stanowczych wniosków dotyczących niezgodności omawianego przepisu z ratyfikowanymi przez Polskę aktami prawa międzynarodowego.

Z funkcjonalnego punktu widzenia pozostaje pytanie o przyczynę ustanawiania przymusu rokowań dla podmiotów, które nie wyrażają woli zawarcia układu zbiorowego pracy. Trzeba pamiętać o tym, że obowiązek przystapienia do rokowań nie gwarantuje zawarcia układu w ich wyniku, nie stwarza dla żadnej ze stron obowiązku doprowadzenia ich do kompromisowego zakończenia, skutkującego zawarciem umowy zbiorowej. Aspektem swobody zawarcia układu zbiorowego powinna być wolność decyzji o przystapieniu do rokowań nad jego powstaniem. Szansę na zawarcie układu stwarza przede wszystkim swobodna decyzja stron o podjęciu negocjacji nad jego treścia, a nie przymus, który może wzbudzać ich opór nieuzasadniony przesłankami merytorycznymi. Regulacja art. $241^{2} \S 3$ k.p. nie wydaje się promować rozwoju regulacji układowej, gdyż zamiast afirmacji swobody stron w kształtowaniu ich sytuacji prawnej, będącej podstawową zaletą autonomicznego prawa pracy, kreuje postrzeganie układów zbiorowych jako instytucji przymusowej.

Ewolucja treści prawnej regulacji układów zbiorowych pracy w Polsce skłania do generalnego wniosku, że próba stworzenia normatywnych podstaw do rozwoju autonomicznego prawa pracy nie została oparta na niezbędnym w społecznej gospodarce rynkowej założeniu zaufania i szacunku dla efektów negocjacji zbiorowych, prowadzonych przez partnerów społecznych. Wady omawianej regulacji prawnej wynikają z tego, że jest ona wyrazem nieufności państwa do twórców układów zbiorowych i ich treści, czego konsekwencją jest przesycenie jej nakazami, wytycznymi, instytucjami nadzoru, które ograniczają autonomię woli stron układów zbiorowych pracy i pozbawiają tę instytucję podstawowego atrybutu swobodnego aktu woli stron w kształtowaniu ich sytuacji prawnej. Powstaje wrażenie, jakby chęć przekazania partnerom społecznym kompetencji regulacyjnych w zakresie zatrudnienia miała nieco pozorny charakter, gdyż państwo równocześnie dążyło do zachowania znacznego wpływu na kształtowanie źródeł autonomicznego prawa pracy ${ }^{18}$.

W ustroju społecznej gospodarki rynkowej zadanie państwa w zakresie tworzenia prawnych podstaw dialogu społecznego powinno polegać przede wszystkim na stworzeniu prawnych podstaw jego prowadzenia, jak też na uznaniu jego materialnoprawnych efektów i włączeniu porozumień społecznych do systemu prawnego. Podstawa partnerstwa społecznego jest zaufanie między podmiotami włączonymi w jego realizację. Dotyczy to nie tylko relacji między przedstawicielami stron stosunków pracy, ale też zaufania państwa do pozytywnych konsekwencji swobodnego dialogu społecznego. Wyrażać się ono powinno w możliwie szerokim zakresie autonomii, jaka państwo pozostawia partnerom społecznym dla samodzielnego kształtowania ich sytuacji. Zaprzeczeniem zaufania jest narzucanie regulacji proceduralnych ukierunkowuja-

18 Wskazuje na to także pierwotna, zmieniona w 2000 r. treść art. 240 § 3 k.p., w którym ograniczono dopuszczalny przedmiotowy zakres regulacji układu zbiorowego pracy w sposób sprzeczny z międzynarodowymi zobowiązaniami RP w tym zakresie. 
cych i zawężających zakres swobodnej współpracy i dialogu. Zbyt restrykcyjny nadzór państwa nad tą sfera jest odbierany jako wyraz jego niechęci do rezygnacji z władczego wpływu na kształtowanie porządku społecznego i nie sprzyja rozwojowi idei partnerstwa.

Powyższe uwagi prowadzą do wniosku, że prawna regulacja ram dialogu społecznego związanego z zatrudnieniem, szczególnie w postaci przepisów działu XI Kodeksu pracy, nie odzwierciedla założeń społecznej gospodarki rynkowej ani nie jest dostosowana do potrzeb tego typu gospodarki. Pokazuje to także praktyka - na początku 2012 r. u ministra właściwego do spraw pracy zarejestrowanych było zaledwie 170 ponadzakładowych układów zbiorowych pracy, jednak w stosunku do $68 \mathrm{z}$ nich dokonano w rejestrze wpisu o ich wygaśnięciu albo wypowiedzeniu. Status dalszych 46 układów jest niejasny, gdyż jedna ze stron, które je zawarły, utraciła swe uprawnienia reprezentacyjne. Oznacza to, że w praktyce w Polsce, w której działa przeszło $2 \mathrm{mln}$ przedsiębiorców, obowiąuje tylko kilkadziesiąt ponadzakładowych układów zbiorowych pracy. Szacuje się, że zgłoszonymi do rejestru ponadzakładowymi układami zbiorowymi pracy objętych jest 390 tys. pracowników ${ }^{19}$. Jest to symbolicznie niewielka liczba wobec $12 \mathrm{mln} 413$ tys. osób zatrudnionych w Polsce jako pracownicy ${ }^{20}$, czy też ok. 8,5 mln osób zatrudnionych w sferze gospodarczej ${ }^{21}$.

Realizacja idei społecznej gospodarki rynkowej napotyka wiele problemów także w dziedzinie legislacji i praktyki zatrudnienia na poziomie indywidualnym. Istotnym pojęciem dla społecznej gospodarki rynkowej jest bezpieczeństwo socjalne. W omawianym modelu państwo obarczone jest obowiązkiem umożliwienia obywatelom zaspokojenia minimalnych potrzeb, bez względu na sytuację życiowa, w jakiej się znaleźli. Idea solidaryzmu społecznego realizowana jest przy zastosowaniu zasady subsydiarności, w której państwo stanowi ostatni podmiot zobowiązany do udzielania wsparcia. Podstawowym obowiązkiem państwa jest natomiast prowadzenie polityki gospodarczej umożliwiającej obywatelom zarobkowanie własną pracą. Pobudzanie gospodarki i osiagnięcie jej stałego wzrostu to podstawowe założenie twórców modelu socjalnej gospodarki rynkowej. Bez tego niemożliwy byłby wzrost dobrobytu całego społeczeństwa. Inaczej jednak niż w podejściu czysto liberalnym w społecznej

${ }^{19}$ Dane ze strony internetowej Departamentu Dialogu i Partnerstwa Społecznego Ministerstwa Pracy i Polityki Społecznej: http://www.dialog.gov.pl/dialog-krajowy/uklady-zbiorowe-pracy/ (dostęp: 20.02.2014).

${ }^{20}$ Zob. Główny Urząd Statystyczny, Kwartalna informacja o aktywności ekonomicznej ludności (I kwartat 2012), http://www.stat.gov.pl/cps/rde/xbcr/gus/pw_kwart_inf_aktywn_ekonom_ ludnosci_1kw_2012.pdf.

${ }^{21}$ Zob. Główny Urząd Statystyczny, Zatrudnienie $i$ wynagrodzenia $w$ gospodarce narodowej w I pótroczu 2012, Warszawa 2012, s. 19. 
gospodarce rynkowej nie zakłada się, że osiągnięcie stałego wzrostu gospodarczego samoistnie rozwiąuje problemy społeczne. Niezbędna jest aktywna prozatrudnieniowa polityka państwa, obejmująca także legislację, służąca osiaganiu jak najwyższego produktywnego zatrudnienia (art. $10 \S 3$ k.p.).

Jednym z dotkliwych problemów współczesnego rynku pracy jest niska jakość wielu miejsc pracy, wyrażająca się pozbawieniem zatrudnionych osób statusu pracowniczego (umowy cywilnoprawne) albo jego ograniczeniem w ramach pracy tymczasowej bądź innych form zatrudnienia elastycznego. Intensywny rozwój tych form zatrudnienia, które nie bez przyczyny potocznie nazywane sa „,́mieciowymi”, jest problemem w kontekście założeń ustrojowych społecznej gospodarki rynkowej. W wielu przypadkach takie zatrudnienie nie realizuje zasad pracy godnej, zakładających uzyskiwanie $\mathrm{z}$ wykonywania pracy środków umożliwiajacych utrzymanie na godziwym poziomie.

W gospodarce rynkowej o charakterze społecznym zarządzanie siłami ludzkimi $\mathrm{w}$ ramach procesu pracy nie może mieć charakteru czysto rynkowego, gdyż humanitarne zasady wykonywania pracy zarobkowej zawieraja się $\mathrm{w}$ - immanentnie związanej z omawianym typem gospodarki - idei upowszechniania dobrobytu. Zasada społecznego charakteru gospodarki implikuje więc konieczność wprowadzenia regulacji prawnych gwarantujących bezpieczeństwo pracy, chroniących ludzi przed wyzyskiem i uprzedmiotowieniem, jako czynnika produkcji poddanego działaniu wolnej konkurencji.

W społecznej gospodarce rynkowej - aby realizowała ona swoje podstawowe założenia - kluczową sprawa jest osiagnięcie równowagi między poziomem zatrudnienia, statusem prawnym wykonawców pracy i efektywnością ekonomiczna, która jest podstawowym celem pracodawców. Wydaje się jednak, że praktyczna sytuacja w Polsce jest daleka od równowagi tych wartości. Powstaje nawet wrażenie, że działalność normodawcza w dziedzinie zatrudnienia przybrała ostatnio bardzo jednostronny charakter, ukierunkowany głównie na redukcję kosztów działalności pracodawców.

We współczesnej gospodarce rynkowej wskazuje się niekiedy na antynomię wartości związanych z wykonawcami pracy, dotyczącą niezgodności między dążeniem do podnoszenia jakości pracy (zakres pracowniczych uprawnień) i utrzymaniem czy wzrostem wielkości zatrudnienia. Ustawodawca powinien wobec tego szukać równowagi między tymi wartościami, aby realizować założenie upowszechniania pracy godnej w wymiarze zarówno indywidualnym (status osoby zatrudnionej), jak i zbiorowym (dostęp do zatrudnienia). W związku z tym może pojawić się dylemat, czy słuszne jest preferowanie rozwiązań legislacyjnych służących wzrostowi zatrudnienia, kosztem jednak obniżenia poziomu uprawnień pracowników ${ }^{22}$. Rozwiązywanie tego problemu w kontekście ustanawiania norm prawnych regulujących różne aspekty pracy zależnej jest nierozerwalnie związane ze współczesną gospodarką i mieści się w założeniach ustrojowych art. 20 Konstytucji.

${ }^{22}$ Zob. M. Skapski, Ochronna funkcja prawa pracy $w$ gospodarce rynkowej, Zakamycze, Kraków 2006, s. 293-389. 
Dużym problemem o charakterze fundamentalnym jest jednak praktyka legislacyjna ostatnich lat, polegająca na ustanawianiu regulacji ukierunkowanych na obniżenie kosztów działalności pracodawców, a wpływających na spadek zarówno wielkości zatrudnienia, jak i jego jakości. Takie normodawstwo stawia pod znakiem zapytania wolę realizacji założeń społecznej gospodarki rynkowej.

Przykładem tego rodzaju legislacji są zmiany regulacji czasu pracy. Powszechnie znaną okolicznościa jest preferencja pracodawców dla minimalizowania liczby osób zatrudnionych w przedsiębiorstwie i przeciążania ich obowiązkami, zamiast zatrudnienia dodatkowych pracowników. Powstaje jednak pytanie, czy prawo pracy - szczególnie w społecznej gospodarce rynkowej powinno tworzyć ramy prawne tego zjawiska, czy też mu przeciwdziałać. Wątpliwe jest, czy praktyka taka jest zgodna z potrzebami rynku pracy, nie mówiąc o interesie zatrudnionych. Regulacja czasu pracy powinna z jednej strony chronić zatrudnionych przed zbyt długimi okresami pracy (dobowo, tygodniowo, rocznie), jednak inną jej istotną funkcja - realizowaną równolegle - jest wymuszanie wzrostu zatrudnienia w przedsiębiorstwie. Brak możliwości legalnego rozszerzania korzystania z pracy danej osoby albo grupy wymusza zatrudnienie kolejnych pracowników. Oddziaływaniu regulacji czasu pracy można więc przypisać charakter zarówno ochronny, jak i promocyjny.

Ewolucja regulacji czasu pracy w ostatnich latach obejmuje rozwój elastycznych form czasu pracy, jak też wydłużanie okresów rozliczeniowych czasu pracy (zob. art. $129 \S 2$ k.p.). Można zaryzykować stwierdzenie, że tendencje te świadczą o odwróceniu dotychczasowego trendu ewolucji regulacji czasu pracy, który od początku jego istnienia polegał na stopniowej poprawie statusu pracowniczego w tym zakresie. Od niedawna zmiany polegaja na wprowadzaniu systemów czasu pracy umożliwiających zatrudnianie pracowników coraz dłużej w skali doby i tygodnia pracy, przy równoczesnym wydłużaniu okresów rozliczania czasu przekraczającego normę czasu pracy. Mimo utrzymania dotychczasowej normy czasu pracy (art. 129 § 1 k.p.), praktyka elastycznego dysponowania jego wymiarem przez pracodawcę powoduje powstawanie coraz dłuższych okresów legalnie wykonywanej pracy z przekroczeniem normy.

Wydaje się oczywiste, że zwiększanie możliwości czasowych dysponowania poszczególnymi pracownikami osłabia potencjał zatrudnieniowy pracodawców, co skłania ich do silniejszego eksploatowania już zatrudnionych osób. Prawo pracy tworzy prawne podstawy tego zjawiska, mimo że jest ono uzasadnione wyłącznie potrzebami gospodarczymi, a ogranicza realizację zarówno promocji zatrudnienia, jak też indywidualnej ochrony pracowników. W świetle wskazanych wyżej funkcji normy prawa pracy w społecznej gospodarce rynkowej powinny raczej stymulować pracodawców do sięgania do rezerw rynku pracy, inwestowania w nowych pracowników przez szkolenie ich, zamiast tworzyć prawne warunki do zwiększania obciążeń stałej albo zmniejszającej się liczby pracowników.

Jedną z funkcji regulacji prawa pracy jest tworzenie warunków maksymalizacji ekonomicznej efektywności, gdyż wzrost gospodarczy ma być podstawą tego modelu gospodarczego. Trzeba jednak pamiętać o tym, że społeczna 
gospodarka rynkowa ma służyć także zapewnieniu równomiernej dystrybucji efektów wzrostu gospodarczego, a prawna regulacja zatrudnienia jest narzędziem realizacji tego celu w stosunku do osób zarobkujących własną praca. Eliminowanie zatem z prawa pracy regulacji służących zarówno wzrostowi zatrudnienia, jak i zarazem zapewnianiu minimalnej indywidualnej ochrony zatrudnionych, z powodu dążenia do obniżenia kosztów pracy, jest działaniem być może adekwatnym w gospodarce rynkowej, ale oderwanym od jej społecznych założeń, które państwo ma obowiązek realizować. Tego typu zwiększone koszty pracy stanowią właśnie o społecznym charakterze gospodarki rynkowej, gdyż służą korekcie rynkowego mechanizmu podziału dóbr, co wyróżnia ten model gospodarki.

Powyższe rozważania prowadzą do wniosku, że podobnie jak w przypadku zbiorowego prawa pracy, również ustanawianie norm indywidualnego prawa pracy nierzadko jest oderwane od założeń społecznej gospodarki rynkowej. Realizacja idei wskazanych w art. 20 Konstytucji w regulacji statusu prawnego stron indywidualnych stosunków pracy wymaga poszukiwania kompromisu między stwarzaniem korzystnych warunków prowadzenia działalności przez pracodawców a dążeniem do zapewnienia godnych warunków życia wykonawcom pracy. To ostatnie oddziaływanie dotyczyć powinno zarówno ustawowego zagwarantowania minimalnych standardów zatrudnienia na godnym poziomie, jak i polityki promujaccej zatrudnienie spełniające standardy pracy godnej. Wadą legislacji prawa pracy, szczególnie w ostatnich kilku latach, jest porzucenie idei zrównoważonego uwzględniania potrzeb wszystkich podmiotów rynku pracy na rzecz tworzenia ram prawnych zwiększania ekonomicznej efektywności zatrudnienia, także kosztem ograniczania jego wielkości czy jakości. Prawo pracy w zbyt małym stopniu jest w Polsce narzędziem typowej dla społecznej gospodarki rynkowej pierwotnej redystrybucji dochodu.

Brak oczekiwanego korzystnego wpływu norm prawa pracy - zgodnie z założeniami społecznej gospodarki rynkowej - wiąże się też z segmentacją ryn$\mathrm{ku}$ pracy, wynikająca z rozwoju niepracowniczych form zatrudnienia, które nierzadko w sposób nielegalny wypierają zatrudnienie pracownicze, gwarantujące wykonawcom pracy lepszy status. Ustawodawca nie podejmuje przy tym zadowalających działań legislacyjnych zmierzających do uporządkowania sytuacji na rynku pracy i wyposażenia administracji rynku pracy w narzędzia umożliwiające wywarcie skuteczniejszego wpływu na jego kształtowanie w kierunku zgodnym z założeniami ustrojowymi.

\section{VI}

Sytuacja polskiego prawa pracy, a także w konsekwencji rynku pracy, obciążona jest jednym $\mathrm{z}$ istotnych zaniechań legislacyjnych III RP, jakim jest niepodjęcie tzw. rekodyfikacji prawa pracy, czyli postulowanego przez doktrynę uchwalenia nowego kodeksu ${ }^{23}$. Sprawa ta była problemem regulacji prawa pracy przez cały okres omawianego ćwierćwiecza, gdyż warunkowała model

${ }^{23}$ Zob. T. Zieliński, Problem rekodyfikacji prawa pracy, „Państwo i Prawo” 1999, z. 7, s. 3-18. 
zmian w nim, opierający się na cząstkowych i oderwanych od siebie nowelizacjach Kodeksu, jak też regulowaniu treści indywidualnego i zbiorowego prawa pracy w ustawach pozakodeksowych.

W pierwszych latach transformacji kontestacja przepisów prawa pracy przez wielu przedsiębiorców była w pewnym stopniu spowodowana ideologicznym osadzeniem tej regulacji w systemie $\mathrm{PRL}^{24}$. Odcięcie się od tego dziedzictwa i symboliczne powiązanie prawa pracy z założeniami społecznej gospodarki rynkowej, dzięki uchwaleniu nowego kodeksu, byłoby niezwykle ważne dla społecznej recepcji tej regulacji prawnej. W późniejszym okresie mniejsze znaczenie miało pochodzenie Kodeksu pracy (uchwalonego 26 czerwca 1974 r.), problemem stały się ograniczone możliwości dalszego dostosowywania tej ustawy do nowych potrzeb regulacyjnych, związanych z tempem i zakresem zmian gospodarczych i postępujących za nimi modyfikacjami rynku pracy i zasad zatrudniania.

Wydaje się, że szczególnie bezpośrednio po wejściu w życie Konstytucji z 1997 r. ewentualne uchwalenie nowego kodeksu pracy, który swymi założeniami nawiązywałby do ostatecznie utrwalonej w art. 20 Konstytucji idei społecznej gospodarki rynkowej, mogło stać się swoistą cezurą dla polskiego rynku pracy, symbolicznym poczattkiem nowego ustroju pracy opartego na nowym ładzie konstytucyjnym. Jakkolwiek nie należy przeceniać wpływu tego typu aktów prawotwórczych na postawy uczestników obrotu gospodarczego, to wydaje się, że uchwalenie nowego kodeksu pracy miałoby wielkie znaczenie zarówno symboliczne, jak i praktyczne.

Obecnie problemem jest to, że nowy kodeks pracy nie został uchwalony ani w tamtym okresie, ani później ${ }^{25}$. Zaniechania tego nie można przypisywać doktrynie czy judykaturze prawa pracy, gdyż środowiska te wniosły wkład $\mathrm{w}$ tworzenie nowych regulacji - uczestniczyły w opracowaniu projektów Indywidualnego kodeksu pracy i Zbiorowego kodeksu pracy, które są efektami pracy Komisji Kodyfikacyjnej Prawa Pracy ${ }^{26}$. Sprawa jakości legislacji z zakresu prawa pracy może być rozpatrywana także w kontekście idei społecznej gospodarki rynkowej. Regulacja zasad zatrudnienia jest sprawą tak ważną dla realizacji założeń społecznej gospodarki rynkowej, że niezrozumiała jest indolencja ustawodawcy dotycząca uporządkowania prawnej regulacji i w szczególności zastapienia najważniejszego aktu prawnego z tej dziedziny, który stał się anachroniczny. Obowiązujący Kodeks pracy nie może być uznany za dysfunkcjonalny, ale na pewno nie jest nowoczesnym aktem dostosowanym do potrzeb współczesnego rynku pracy. Jego dalsze obowiązywanie jest więc kolejnym argumentem wskazującym na niezadowalające zaangażowanie ustawodawcy w realizację założeń społecznej gospodarki rynkowej w polskim ustroju pracy.

${ }^{24}$ Zob. preambułę do Kodeksu pracy, uchyloną w ustawie z 2 lutego 1996 r. o zmianie ustawy Kodeks pracy oraz o zmianie niektórych ustaw, Dz. U. Nr 24, poz. 110.

${ }^{25} \mathrm{Na}$ temat zagadnień rekodyfikacji prawa pracy zob. L. Florek, Kodyfikacyjne problemy prawa pracy oraz W. Sanetra, Niektóre sporne zagadnienia kodyfikacji prawa pracy, w: Problemy kodyfikacji prawa pracy, op. cit.

${ }^{26}$ Zob. http://www.mpips.gov.pl/prawo-pracy/projekty-kodeksow-pracy/. 


\section{VII}

Przyjęcie społecznej gospodarki rynkowej za podstawę ustroju gospodarczego Rzeczypospolitej na początku transformacji było wyborem trafnym, gdyż model ten najbardziej odpowiada polskiemu dziedzictwu kulturowemu i gospodarczemu. Niestety powyższe uwagi wskazuja, że zarówno treść prawnej regulacji, jak i praktyka rynku pracy wykazują nadal wiele rozbieżności z założeniami społecznej gospodarki rynkowej. Wydawałoby się, że ćwierć wieku to wystarczający okres, aby w dziedzinach tych dokonały się zasadnicze zmiany, w kierunku wskazanym w art. 20 Konstytucji. Jednakże dotychczasowy zakres ich transformacji nie jest zadowalający, chociaż uwzględniając ustrój pracy przełomu lat osiemdziesiątych i dziewięćdziesiątych, który stanowił punkt wyjścia przemian, nie można mówić o porażce transformacji, gdyż przeprowadzone zmiany sa rozległe i fundamentalne.

Można jednak odnieść wrażenie, że przemiany ustroju pracy dokonywały się w dużej mierze samoistnie, jako rezultat spontanicznie kształtującej się praktyki rynku pracy, a państwo jedynie reagowało - i to z opóźnieniem na nowe zjawiska, zamiast odgrywać rolę stymulującą i wymuszać pożądany kierunek ewolucji. Inicjująca rola państwa w kształtowaniu kierunku transformacji wymagana jest szczególnie w tworzeniu społecznej gospodarki rynkowej, gdyż jego bierność właściwa jest raczej doktrynie leseferyzmu i prowadzi do ukształtowania liberalnego modelu rynku pracy.

Rozbieżności cech polskiego ustroju pracy z modelem społecznej gospodarki rynkowej są więc w pewnym zakresie wynikiem wad legislacji, polegających zarówno na wyżej opisanych zaniechaniach ustawodawcy, jak też na uchwalaniu już w okresie transformacji regulacji prawnych niekorelujących z nowymi założeniami ustrojowymi. Trzeba jednak wskazać, że częściowy tylko sukces budowy ustroju pracy opartego na społecznej gospodarce rynkowej związany jest i z koniecznością przezwyciężenia dziedzictwa PRL w uwarunkowaniach społecznych i kulturowych, których kształtowanie wymaga być może więcej czasu.

Mimo przyjętego na wstępie artykułu założenia, dotyczącego traktowania transformacji ustrojowej jako procesu dokonanego, w odniesieniu do przemian regulacji rynku pracy, szczególnie prawa pracy, należy sformułować postulat jej kontynuacji. Dotychczasowa ewolucja rynku pracy III RP doprowadziła do powstania społecznych stosunków pracy eksponujących antagonizmy jego podmiotów, a nie partnerstwo społeczne, solidarność i prymat dobra wspólnego. Mimo że wraz z utrwalaniem się niekorzystnych zwyczajów coraz trudniej o zmiany, należy dążyć do pełniejszej realizacji wartości wskazanych w art. 20 Konstytucji.

dr hab. Michat Skapski

Profesor Uniwersytetu im. Adama Mickiewicza w Poznaniu skapski@amu.edu.pl 


\title{
REALISATION OF THE IDEA OF SOCIAL MARKET ECONOMY IN POLISH LABOUR REGIME
}

\author{
Sum mary
}

Social market economy has been the desired model of economy since the beginning of the political and economic transformations in Poland initiated in 1989. In 1997, pursuant to the provision of article 20 of the new Constitution of the Republic of Poland, it became the normative foundation of the country's political regime. Today, twenty five years later, one may wish to analyse the effects of these changes and compare the contents of currently binding regulations of employment issues and labour market practices with the social market economy model which lay at their formulation.

Social relations, regulated by collective labour law achieved through the activity of trade unions and employers' organisations, collective negotiations and creation of the sources of autonomous law, belong to these areas, which are most neglected in Poland in terms of their compliance with the basic assumptions of social market economy. They aim, among other things, at implementing a social partnership model and workers' participation as active subjects in the dialogue with employers on matters concerning the conditions of an enterprise, resolving problems and disputes by way of collective negotiations leading to collective agreements. In Poland, this concept is still given only marginal attention.

This paper also identifies problems that arise from implementation of the idea of a social market economy in the practice of individual labour law. Legislative tendencies of the recent years focus on the economic efficiency of enterprises, also at the cost workers' status, rather than sustained development of economy, fostering for the needs of all subjects involved in the functioning of the enterprise.

With due respect to the achievements of the transformations in Poland after 1989, full implementation and realisation of the constitutional provisions of article 20 constituting grounds for the political regime, has not yet been achieved. 
Copyright of Journal of Law, Economics and Sociology is the property of Faculty of Law and Administration of Adam Mickiewicz University in Poznan and its content may not be copied or emailed to multiple sites or posted to a listserv without the copyright holder's express written permission. However, users may print, download, or email articles for individual use.

Właścicielem praw autorskich do „Ruchu Prawniczego, Ekonomicznego i Socjologicznego” jest Wydział Prawa i Administracji Uniwersytetu im. Adama Mickiewicza w Poznaniu. Zawartość czasopisma nie może być kopiowana, przesyłana do innych stron internetowych bądź zamieszczana na blogach bez pisemnej zgody wydawcy. Niemniej artykuły można drukować, kopiować lub przesyłać w formie elektronicznej na własny użytek. 